\title{
The Impact of COVID-19 on Turkish Forest Products Industry
}

\author{
Bahadır Çağrı BAYRAM ${ }^{1, *}$ \\ ${ }^{1}$ Kastamonu University, Faculty of Forestry, Forest Industry Engineering Department, 37150, Kastamonu.
}

\begin{abstract}
In the present paper the impact of COVID-19 pandemic on Turkish forest products industry was investigated with the help of qualitative research methods. Focus groups and interview methods were adopted as the methodology. The scope of the study is limited to wood-based panel, laminate flooring and furniture industries which are the leading branches within forest products industry of Turkey. The respondents are white-collar workers randomly chosen from engineers, managers or marketing directors of large-sized enterprises from Ankara and Bursa. The enterprises were limited with mentioned cities due to these cities are of great importance for the industry in management and marketing activities. Results showed that COVID-19 pandemic affected the labour force and income negatively. The key finding of this work is that if the pandemic lasts longer the substantialeconomic side effects will be inevitable. Also, the results suggest that at first the companies should focus on raw material supply and secondly to domestic market rather than the international market.
\end{abstract}

Keywords: COVID-19, economic impact, Turkey, forest products, industry.

\section{COVID-19'un Türkiye Orman Ürünleri Endüstrisine Etkisi}

\section{Öz}

Bu makalede COVID-19 salgınının Türkiye orman ürünleri endüstrisiüzerindeki etkisi nitel araştırma yöntemleri yardımıyla araştırılmıştır. Metodoloji olarak odak grupları ve görüşme yöntemleri benimsenmiştir. Çalışmanın kapsamı, Türkiye orman ürünleri sektörünün önde gelen dalları olan ahşap esaslı panel, laminat parke ve mobily a sektörleri ile sınırlıdır. Katılımcılar, Ankara ve Bursa'da faaliyet gösteren büyükölçekli işletmelerin mühendisleri, yöneticileri veya pazarlama müdürleri arasından rastgele seçilen beyaz yakalı çalışanlardır. İşletmelerin adı geçen şehirlerle sınırlı kalması, bu şehirlerin yönetim ve pazarlama faaliyetlerinde endüstri için büyükönem taşımasından dolayıdır. Sonuçlar, COVID-19 salgınının işgücünü ve geliri olumsuz etkilediğini göstermektedir. Bu çalışmanın en önemli bulgusu, pandemi daha uzun sürerse ciddi ekonomik yan etkilerin kaçınılmaz olacağıdır. Ayrıca sonuçlar, şirketlerin öncelikle hammadde tedarikine, ikinci olarak da uluslararası pazar yerine iç pazara odaklanmaları gerektiğini göstermektedir.

Anahtar Kelimeler: COVID-19, ekonomik etki, Türkiye, orman ürünleri, endüstri. 


\section{Introduction}

With unprecedented scale and severity, the COVID-19 pandemic is a global disaster that has wreaked havoc on people's lives and livelihoods (CCSA, 2020). The pandemic has altered macro dynamics, from national economy and public health to international trade, transportation, and defense (Fu et al., 2020). It was firstly identified in Wuhan, China in December 2019 and then has spread across the globe (URL-1, 2021; Baek et al., 2020). Figure 1. and Figure 2. demonstrates the latest global situation related to pandemic.

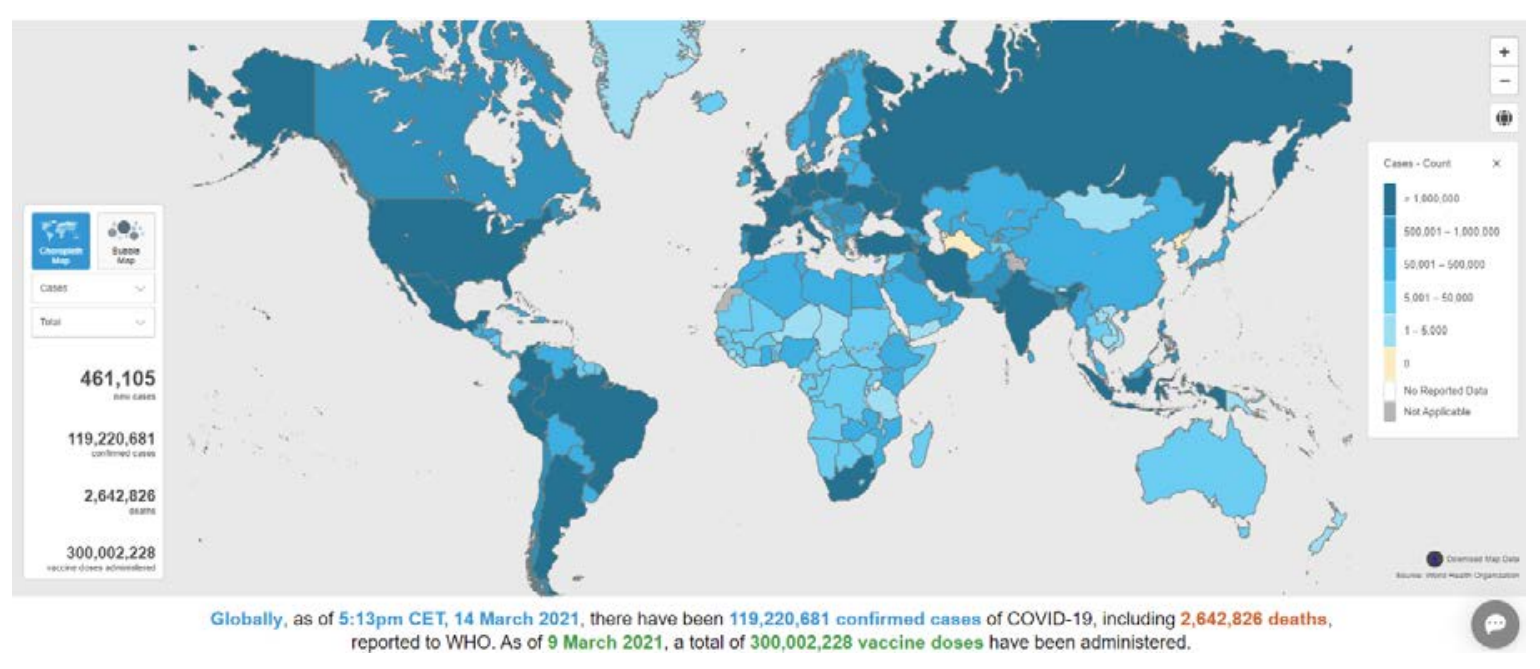

Figure 1.Latest global situation of COVID-19 outbreak as of March 15, 2021 (URL-2, 2021).

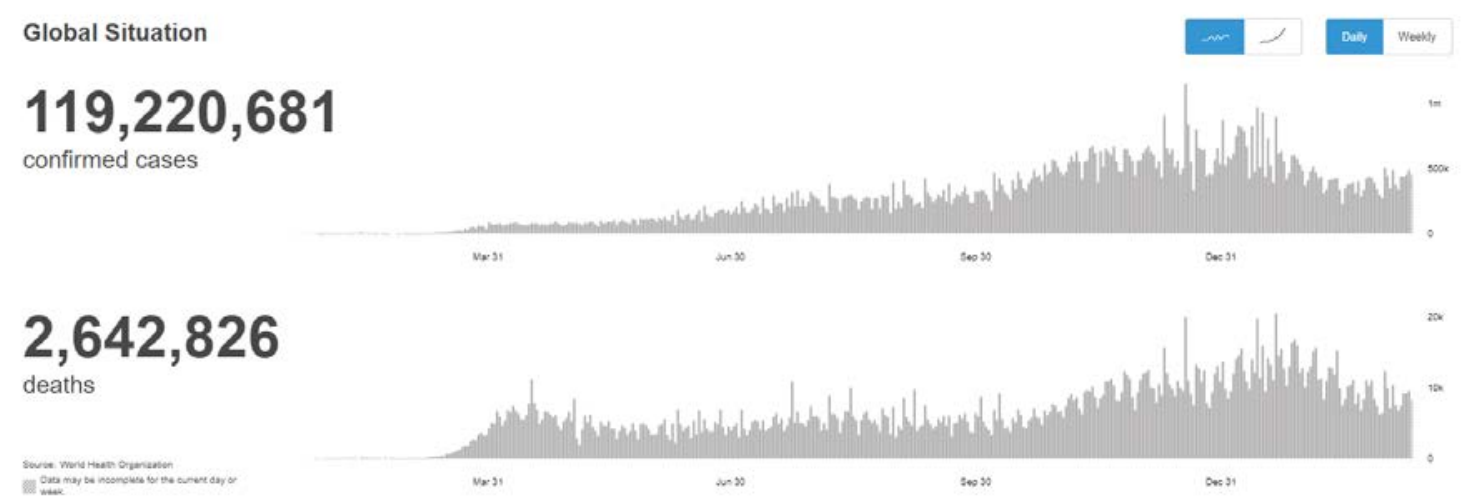

Figure 2. Global situation of COVID-19 outbreak in details as of March 15, 2021 (URL-2, 2021).

The COVID-19 pandemic caused the worst global recession since 1930 and many countries su corporate bankruptcies and job losses (Shen et al., 2020). Unfortunately, as in rest of the world, Turkey has been impacted by COVID-19 deeply (World Bank, 2020). The Turkish economy, whilst already struggling with a volatile currency and high-risk market for borrowing, has become vulnerable to global financial devastation due to the COVID-19 pandemic (EDAM, 2020). Even though the authorities took swift and comprehensive fiscal, monetary and financial measures to control the economic impact of COVID-19, important sectors remain vulnerable to COVID-19 related economic strains (World Bank, 2020; EDAM, 2020). 
In Turkey, from 3 January 2020 to 5:13pm CET, 14 March 2021, there have been 2,866,012 confirmed cases of COVID-19 with 29,421 deaths, reported to WHO. As of 8 March 2021, a total of 10,222,994 vaccine doses have been administered.

Turkey Situation

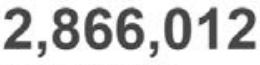

confirmed cases

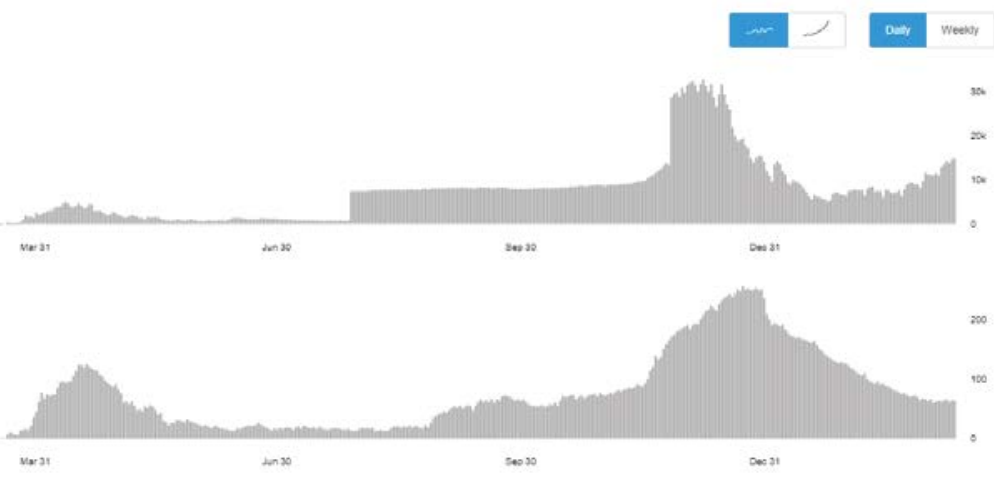

Figure 3. Turkey’s situation of COVID-19 outbreak in details as of March 15, 2021 (URL-3, 2021).

One of the driving industries of Turkish economy, forest products (FP) industry is of great importance amongst other manufacturing industry branches (Bayram, 2020). In the Turkish FP industry, employers range from very small firms to large international firms, and enterprises can be located in both developed regions and rural areas (Gedik et al., 2016). The forest products industry comprises of the following forest products and product aggregates: industrial roundwood, sawn wood, wood-based panels, fiber furnish, paper and paper board, wood fuel, charcoal and pellets (FAO, 2018).

There is a growing body of literature that recognises the importance of COVID-19 both for the global and national economies. Several attempts have been made to evaluate the impact of COVID-19 in various fields. For instance: Song et al. (2021) investigated the economic impact of the COVID-19 in the U.S. restaurant industry, Skare et al. (2021) examined the impact of COVID-19 on the travel and tourism industry, Laing (2020) evaluated the economic impact of the COVID-19 for the mining industry, Babuna et al. (2020) investigated the economic impact of COVID-19 on the insurance industry, Siche (2020) examined the impact of COVID-19 on agriculture.

Surprisingly, the economic impact of COVID-19 on forest products industry has not been extensively investigated. There is little published information on the related subject e.g., Hayes and Morgan (2020) evaluated the Montana wood products industry in the time of COVID-19, Ratnasingam et al. (2020) investigated how Malaysia's small and medium sized furniture enterprises are coping with COVID-19 pandemic and Liu et al. (2020) examined the COVID-19 challenges for the pulp and paper industry in the world. Hence, it can be said that there is a notable paucity of scientific literature specifically relating to COVID-19 and forest products industry. Therefore, the present study was designed to investigate the impact of COVID-19 particularly on forest products industry of Turkey. The aim of the present paper is to reveal the economic consequences of this pandemic on Turkey's FP industry and also to contribute the body of literature.

This study is unable to encompass the entire industry due to COVID-19 restrictions and, time and financial constraints. The present paper deals with only large-sized forest product enterprises that are operating in different areas such as wood-based panel, laminate flooring and furniture industries which are the leading branches within forest products industry of Turkey. In Turkish FP industry, furniture industry is of great importance due to its number of workplaces, level of employment and foreign trade surplus (Ersen, 2021).

Small and medium sized enterprises, and other subsectors are out of the scope of this research. In this paper focus groups and interview methods, which are among the qualitative research methods, were employed and they will be given in detail in material and methods section. The respondents are white-collar workers randomly chosen from engineers, managers or marketing directors.

\section{Material and Methods}

The present study is a qualitative research. Despite the deeply conducted literature research, unfortunately there are not many quantitative data on the economic impacts of COVID-19 phenomenon were able to found. The majority of the data on COVID-19 and its impacts are naturally related to health. Consequently, qualitative research 
methods were adopted for this work and the findings are based on expert opinions. Qualitative research is an interpretative approach (Palmer and Bolderston, 2006) in which, the researcher generally explores meanings and insights in a given situation (Mohajan, 2018). It is one of the social science research methods and works with nonnumerical data (Punch, 2013). Qualitative research includes the following methods: logic, discourse analysis, ethnography, case study, open-ended interview, participant observation, counseling, therapy, grounded theory, biography, comparative method, introspection, casuistry, focus group, literary criticism, historical research, etc. (Cibangu, 2012). Data collection methodologies that are mostly used in qualitative research are the interview, the focus group, observation and/or chart review (Palmer and Bolderston, 2006). The focus groups and interview methods were used at the present work. The interview offers the possibility of a deeper understanding of the interviewee's experiences. There are three types of interview approaches; namely structured, semi-structured and unstructured interviews (Palmer and Bolderston, 2006). Unstructured interviews were adopted in the pres ent study. It is known that the data generated from unstructured interviews can be rich and provide more in-depth appreciation of a subject matter than a questionnaire (Bell, 1999). On the other hand, focus group is also a type of interview but which is done with a larger group of people. It is a moderated discussion with a small group of participants (5-10) about a particular subject that aims to identify and understand the participants' views (Gegez, 2007; Palmer and Bolderston, 2006; Nakip, 2005). The focus group interviews are divided into two: full focus group and mini focus group (Greenbaum, 1998). Mini focus group interviews were employed at the present study. This choice was made due to usefulness of the mini focus group particularly for discussing sensitive topics (Daymon and Holloway, 2011). The data were collected with online interview approach. Online interview is a research method in which the interviews are carried out with computer-mediated communication to collect data. Data collection with online interview approach is convenient and low-cost (Salmons, 2014). The participants contributed to the present study were selected randomly from various and large-sized forest product enterprises that are operating in different leading areas such as wood-based panel, laminate flooring and furniture industries from Ankara and Bursa. The enterprises were limited with mentioned cities due to these cities are of great importance for the industry in management and marketing activities. The respondents are white-collar workers randomly chosen from engineers, managers or marketing directors. They are seven people in total. Five of them are members of the mini focus group whilst the remaining two are interviewees.

Table 1. Demographics of experts.

\begin{tabular}{cccc}
\hline Gender & Age & Expertise & Field of Expertise \\
\hline Male & 34 & 12 Years & Laminate flooring \\
Male & 34 & 9 Years & Furniture industry \\
Male & 45 & 25 Years & Wood-based panels \\
Male & 40 & 20 Years & Laminate flooring \\
Male & 35 & 8 Years & Wood-based panels \\
Female & 29 & 7 Years & Furniture industry \\
Male & 31 & 6 Years & Furniture industry \\
\hline
\end{tabular}

\section{Results and Discussion}

In general, at the beginning of the COVID-19 pandemic: firstly, import and export companies suffered a great deal of economic damage due to the stopping of material supply and product shipment because of the closed customs gates. Ready-to-ship furniture and similar products could not be shipped for weeks and months at customs gates, this situation caused an economic collapse for the companies that could not receive their payments due to not shipped goods. Many workers became unemployed due to unpaid wages linked to missed orders. In addition, companies working on order have completed their orders using the last raw materials they have, but the trade network has bottlenecked, as the companies that supply raw materials have closed their companies or switched to flexible working programs.

It seems possible that these results are due to lockdowns around the world. Considering the limited working hours and reduced community mobility, these results are not surprising. It can therefore be assumed that the economic disadvantages of COVID-19 will disappear with the end of the pandemic. In particular, factories have started to take precautions since the pandemic emerged in Turkey as of March 2020. The findings are cumulatively listed as follows: 
In the vast majority of the industry;

- Most of the white-collar employees were started to work from home until the 1st of June, 2020.

- $\quad$ Production staff and shifts have been significantly reduced.

- In some of the factories the production capacity was reduced to 50\% as of March, 2020.

- $\quad$ Export sales were heavily affected until the end of April, 2020. In some sectors the export amount was below the reduced production capacity.

- Domestic market sales fell by 30\%. Especially in April and May.

- With the beginning of the normalization process as of 1 June; domestic market sales increased by around 150\% until August. Due to the increase in loan interest rates in Turkey in August, sales receded to $80 \%$. As of September, with the completion of the remaining works and the effect of the dynamism in the projects, it started to rise again.

- $\quad$ Due to the increase in export sales as of June, deadlines have more than doubled.

- Amid the COVID-19 pandemic, the difficulties of finding raw materials started due to the capacity reductions of domestic and foreign companies that supply raw materials. With the decrease in raw material production, product prices started to increase by $45 \%$. This situation created the obligation to increase the prices of sold products.

- In the coming periods, there will be a decrease in sales due to the worsening seasonal conditions especially in the domestic market and the slowdown in the construction sector. In addition, it is thought that there will be further contraction with the arrival of the pandemic second wave.

- Raw material stock holding times will be shorter, sales systems will concentrate on credit card or cash from forward sales, employment problems will be experienced due to working half-capacity. Also, even if the employees do not lose their jobs, due to not working at full capacity a decrease in income will put employees in a difficult situation.

Particularly in furniture industry;

- Production in most of the manufacturing factories stopped in April and May 2020. At the end of May, with the starting normalization process and marketing campaigns the factories started to work at an intensity of up to 200\%. Exports started to increase with the resumption of shipments. However, exports nearly stopped especially in the first months.

- When sales are very intense firms that caught without stocks had difficulties in finding labour force to work in increasing shifts.

These results must be interpreted with caution because it may be somewhat limited by the number of participants and represented sectors. As was mentioned in the material and methods section, the companies are operating in different leading areas such as wood-based panel, laminate flooring and furniture industries and not all of the subsectors of forest products industry are included. However, these findings may help us to better understand and cope with the impact of COVID-19 in forest products industry. For better insight, a further study with more focus on various subsectors is therefore suggested.

\section{Conclusions}

This study set out to reveal the impacts of COVID-19 pandemic on Turkish forest products industry. The research has shown that the pandemic affected the labour force and income negatively. The most obvious finding to emerge from this study is that if the pandemic lasts longer the substantial economic side effects will be inevitable. Taken together, the results suggest that at first the companies should focus on raw material supply and secondly to domestic market rather than the international market. The present study aims to laying the groundwork for future research into COVID-19 and forest products industry.

\section{Acknowledgements}

The author would like to thank Mr. Sedat ALP, Forest industry engineer for their valuable contribution in data collection process.

\section{References}

1. Babuna, P., Yang, X., Gyilbag, A., Awudi, D. A., Ngmenbelle, D., \& Bian, D. (2020). The impact of 
Covid-19 on the insurance industry. International journal of environmental research and public health, 17(16), 5766.

2. Baek, S., Mohanty, S. K., \& Glambosky, M. (2020). COVID-19 and stock market volatility: An industry level analysis. Finance Research Letters, 37, 101748.

3. Bayram, B. Ç. (2020). Evaluation of forest products trade economic contribution by entropy-TOPSIS: Case study of Turkey. Bioresources, 15(1), 1419-1429.

4. Bell, J. (2014). Doing Your Research Project: A guide for first-time researchers. McGraw-Hill Education (UK).

5. CCSA (2020). How Covid-19 is changing the world: a statisticalperspective, Volume I, The Committee for the Coordination of Statistical Activities. Available at: https://data.unicef.org/wpcontent/uploads/2020/07/covid19-report-ccsa.pdf

6. Cibangu, K. S. (2012). Qualitative research: The toolkit of theories in the social sciences. Theoretical and methodological approaches to social sciences and knowledge management, 95-126.

7. Daymon, C., \& Holloway, I. (2011). Qualitative research methods in public relations and marketing communications. (2nd ed.). Routledge.

8. EDAM (2020). The political and economic impact of the coronavirus pandemic in Turkey, Istanbul.

9. Ersen, N. (2021). Analysis of furniture products' contribution to Turkey's economy with a hybrid multicriteria decision-making method. Bioresources, 16(1), 339-354.

10. Food and Agriculture Organization of The United Nations (FAO) (2018). FAO Yearbook of forest products 2016. Food and agriculture organization of the United Nations publisher, Rome.

11. Fu, H., Hereward, M., MacFeely, S., Me, A., \& Wilmoth, J. (2020). How COVID-19 is changing the world: A statistical perspective from the Committee for the Coordination of Statistical activities. Statistical Journal of the IAOS, 36(4), 851-860.

12. Gedik, T, Şahin, H, Çil, M. (2016). Merkezi Yerleştirme Sonuçlarına göre orman endüstrimühendis liğinin tercih edilme durumunun değerlendirilmesi, Kastamonu University Journal of Forestry Faculty, 16 (1), 9095.

13. Gegez, E (2007). Pazarlama Araştırmaları [Marketing Researches]. İstanbul: Beta Basım Yayım, Genişletlmiş 2. Basim.

14. Greenbaum, T. L. (1998). The handbook for focus group research. Sage.

15. Hayes, S., \& Morgan, T. A. (2020). Forest Products: Montana Wood Products in the Time of COVID-19. Montana Business Quarterly, 58(4), 35-37.

16. Laing, T. (2020). The economic impact of the Coronavirus 2019 (Covid-2019): Implications for the mining industry. The extractive industries and society, 7(2), 580-582.

17. Liu, K., Wang, H., Liu, H., Nie, S., Du, H., \& Si, C. (2020). COVID-19: Challenges and perspectives for the pulp and paper industry worldwide. BioResources, 15(3), 4638-4641.

18. Mohajan, H. K. (2018). Qualitative research methodology in social sciences and related subjects. Journal of Economic Development, Environment and People, 7(1), 23-48.

19. Nakip, M. (2005). Pazarlama Araştırmalarına Giriş: SPSS Destekli. [Introduction to Marketing Research: Supported by SPSS.] Ankara: Seçkin Yayıncılık, 2. Bask1.

20. Palmer, C., \& Bolderston, A. (2006). A brief introduction to qualitative research. Canadian Journal of Medical Radiation Technology, 37(1), 16-19.

21. Punch, K. F. (2013). Introduction to social research: Quantitative and qualitative approaches. Sage publications.

22. Ratnasingam, J., Khoo, A., Jegathesan, N., Wei, L. C., Abd Latib, H., Thanasegaran, G., ... \& Amir, M. A. (2020). How are small and medium enterprises in Malaysia's furniture industry coping with COVID19 pandemic? Early evidences from a survey and recommendations for policymakers. BioResources, 15(3), 5951-5964.

23. Salmons, J. (2014). Qualitative online interviews: Strategies, design, and skills. (2nd ed.). Sage Publications.

24. Shen, H., Fu, M., Pan, H., Yu, Z., \& Chen, Y. (2020). The impact of the COVID-19 pandemic on firm performance. Emerging Markets Finance and Trade, 56(10), 2213-2230.

25. Siche, R. (2020). What is the impact of COVID-19 disease on agriculture? Scientia Agropecuaria, 11(1), 36.

26. Škare, M., Soriano, D. R., \& Porada-Rochoń, M. (2021). Impact of COVID-19 on the travel and tourism industry. Technological Forecasting and Social Change, 163, 120469.

27. Song, H. J., Yeon, J., \& Lee, S. (2021). Impact of the COVID-19 pandemic: Evidence from the US restaurant industry. International Journal of Hospitality Management, 92, 102702.

28. URL-1 (2021): https://www.who.int/news/item/27-04-2020-who-timeline---covid-19 (08.03.2021)

29. URL-2 (2021): https://covid19.who.int/ (08.03.2021)

30. URL-3 (2021): https://covid19.who.int/region/euro/country/tr(08.03.2021)

31. World Bank (2020). Turkey economic monitor, August 2020: Adjusting the sails. 